\title{
Experimental investigation of time-dependent local scour downstream of a stepped channel
}

\author{
Aysegul Ozgenc Aksoy' and Mustafa Dogan ${ }^{1 *}$ \\ 'Civil Engineering Dept., Dokuz Eylul University, Izmir, Turkey
}

\begin{abstract}
In this study, temporal variation of local scour occurring at the downstream part of the stepped channel were investigated experimentally. The experimental tests were carried out in a stepped flume with a height of $2.4 \mathrm{~m}$. The width of the rectangular flume was $0.10 \mathrm{~m}$ and the length of the stilling basin was $2.12 \mathrm{~m}$. Bed material was placed in a sediment box with a height of $24 \mathrm{~cm}$ and length of $2.48 \mathrm{~m}$, without any compaction. Experiments were carried out by using bed material of 4 different grain size distributions, 2 different sill heights and 6 different flow rates. Two empirical equations which include Shields parameter $(\theta)$ and densimetric Froude particle number $\left(F_{d}\right)$ were proposed by using the experimental findings to predict the temporal variation of the scour depth. The $R^{2}$ (coefficient of determination) values were computed for both proposed equations as 0.866 and 0.865 . The scatter index (SI) values were also determined and computed as $8.73 \%$ and $8.25 \%$. The fit of the equations was also determined by means of Fisher's test.
\end{abstract}

Keywords: stepped channel, local scour, temporal variation

\section{INTRODUCTION}

Stepped channels are currently preferred because they provide substantial energy dissipation and accordingly reduce the size of the downstream stilling basin. Stepped channels also result in reduced construction time and so have a large number of applications in engineering. Flow regimes above stepped channels can be described as nappe flow, transition flow and skimming flow. In the nappe flow regime, the water proceeds in a series of plunges from one step to another. In a skimming flow regime, the water flows down the stepped face as a coherent stream skimming over the steps and cushioned by the recirculating fluid trapped between them (Chanson, 1994).

At the downstream end of stepped channels, supercritical flow generally occurs and subcritical flow is observed at the end of the downstream stilling basin. Local scour around hydraulic structures is considered to be an important phenomenon affecting their stability. Estimation of local scour downstream of stepped spillways is an important task for hydraulic engineering. To date, many scour experiments have been carried out and empirical equations developed to estimate the scour depth that occurs downstream of spillways (Hassan and Narayanan, 1985; Breusers and Raudkivi, 1991; Oliveto and Comuniello, 2009; Oliveto et al., 2011)

Tuna and Emiroglu (2011) investigated the scour hole profile downstream of stepped chutes. They also presented equilibrium scour depth values, the location of the maximum scour depth and the length of the scour hole.

Tuna (2012) studied the impact of the offtake channel base angle of stepped spillways on the scour hole, by means of a physical model. According to the experimental results it was revealed that a take-off angle of $30^{\circ}$ is the optimum angle which gives the minimum longitudinal area and maximum depth of the scour hole.

Tuna and Emiroglu (2013) investigated the effect of step geometry on the dynamics of local scour processes downstream of a stepped chute. Experimental results showed

*Corresponding author, email: mustafa.dogan@deu.edu.tr Received 5 July 2018; accepted in revised form 13 June 2019 that the equilibrium depth of scour is highly dependent on the step geometry.

Farhoudi and Shayan (2014) investigated local scour downstream of adverse-slope stilling basins. Experiments were conducted for different stilling basin slopes. The experimental results revealed that the length of the scour profiles and the volume of eroded materials increased in accordance with the slope of the basin. The time evolution of scour hole dimensions and the equilibrium state were also defined.

Aminpour et al. (2016) investigated the time scale of local scour evolution downstream of stepped spillways. Experiments were conducted using stepped spillways with a height of $45 \mathrm{~cm}$ and $60 \mathrm{~cm}$. The results show that the dimensions of the scour hole increase with densimetric Froude particle number. It was also revealed that the energy dissipation achieved by stepped spillways under specific conditions is higher than that of ogee spillways.

Elnikhely (2017) investigated local scour downstream of a spillway by means of cylinder blocks fixed on the back slope of the spillway. Based on the experimental results it was concluded that cylinder blocks can be used as an extra element over existing spillway structures for minimizing of scour.

The temporal evolution of scour depth $\left(d_{s}\right)$ is also an important element in understanding the scour process. Few studies have focused on the temporal evolution of scour depth. The parameters having an effect on the scour process are the flow parameters, such as velocity $(V)$, tailwater depth $\left(h_{t}\right)$, fluid density and viscosity ( $\rho$ and $\mu$ ), bed material (sediment) characteristics, and time.

The main objective of this study was to investigate the temporal variation of scour downstream of the stilling basin and to propose an empirical equation based on experimental data.

\section{DIMENSIONAL ANAYSIS}

In the local scour process, the effective dimensional parameters are: density of the water $(\rho)$, kinematic viscosity of the water $(v)$, density of the bed material $\left(\rho_{s}\right)$, median grain size of the bed material $\left(d_{50}\right)$, step height $(h)$, step width $(b)$, stilling basin length $(l)$, sill height $\left(h_{s}\right)$, tailwater depth $\left(h_{t}\right)$, velocity of the 
water $(V)$, acceleration due to gravity $(g)$ and time $(t)$. Thus the value of the scour depth can be written as:

$$
d s=f_{1}\left(\rho, v, \rho_{s}, d_{50}, h, b, l, h s, h t, V, g, t\right)
$$

The independent parameters $\rho, \rho_{\mathrm{s}}$ and $g$ can be combined as $g^{\prime}$ where $g^{\prime}=\left[\left(\rho_{s}-\rho\right) / \rho\right] g$ (Dey and Raikar, 2005) and under turbulent flow conditions the effect of $v$ can be neglected. In addition, Densimetric Froude particle number $\left(F_{d}\right)$ has an important role in the temporal dimension of the scour process (Oliveto and Hager, 2002) and is defined as $F_{d}=V / g^{\prime} d_{50}$ ) Dimensionless time parameter can be expressed as (Oliveto et al., 2011):

$$
T=\left(\sqrt{g^{\prime} d_{50}} / h\right) * t
$$

The non-dimensional parameters were obtained by means of Buckingham $\pi$ theorem as:

$$
\frac{d_{s}}{h}=f_{2}\left(\frac{d_{50}}{h}, \frac{b}{h}, \frac{l}{h}, \frac{h_{s}}{h}, \frac{h_{t}}{h}, F_{d}, \frac{\sqrt{g^{\prime d_{50}}}}{h} t\right)
$$

Median grain size of the bed material $\left(d_{50}\right)$ is considered in $F_{d}$ and the non-dimensional time term. The tailwater depth $\left(h_{t}\right)$ depends on the sill height $\left(h_{s}\right)$. The values of $(b / h)$ and $(l / h)$ are constant for the present study. Thus the non-dimensional effective parameters can be written as:

$$
\frac{d_{s}}{h}=f_{3}\left(\frac{h_{t}}{h}, F_{d}, \frac{\sqrt{g^{\prime d_{50}}}}{h} t\right)
$$

In sediment transport, the initiation of motion of sediment in a fluid flow can be determined by using the dimensionless Shields parameter $(\theta)$ which is defined as:

$$
\theta=u_{*}^{2} /\left(g^{\prime} d_{50}\right)
$$

So $\theta$ can also be used instead of $F_{d}$ in Eq. 3 .

\section{EXPERIMENTAL SETUP}

The experimental tests were carried out in a stepped flume with a height of $2.4 \mathrm{~m}$ as shown in Fig. 1. The flume was constructed as a $1 / 10$ scale partial physical model of the Cine Adnan Menderes Dam stepped spillway in the Hydraulic Laboratory of the Civil Engineering Department at Dokuz Eylul University. The sidewalls were made of plexiglass material to observe the flow and scour process. The width of the rectangular flume was $0.10 \mathrm{~m}$ and the length of the stilling basin was $2.12 \mathrm{~m}$. Bed material was placed in a sediment box with a height of $24 \mathrm{~cm}$ and length of $2.48 \mathrm{~m}$. The water was pumped from a $30 \mathrm{~m}^{3}$ main reservoir to the stilling tank of the experimental set-up using a centrifugal pump.

Experiments were carried out by using bed materials of 4 different grain size distributions $(0.55-5.45 \mathrm{~mm})$, 2 different sill heights $(5.0-7.5 \mathrm{~cm})$ and 6 different flow rates $\left(2739-8402 \mathrm{~cm}^{3} / \mathrm{s}\right)$. The step height was $12 \mathrm{~cm}$ during the experiments. Bed materials were placed without compaction or any other treatment. The disturbed bed was flattened to obtain a horizontal plane surface before starting a new experiment. Particle size distributions of the bed materials used in the experiments are given in Fig. 2.

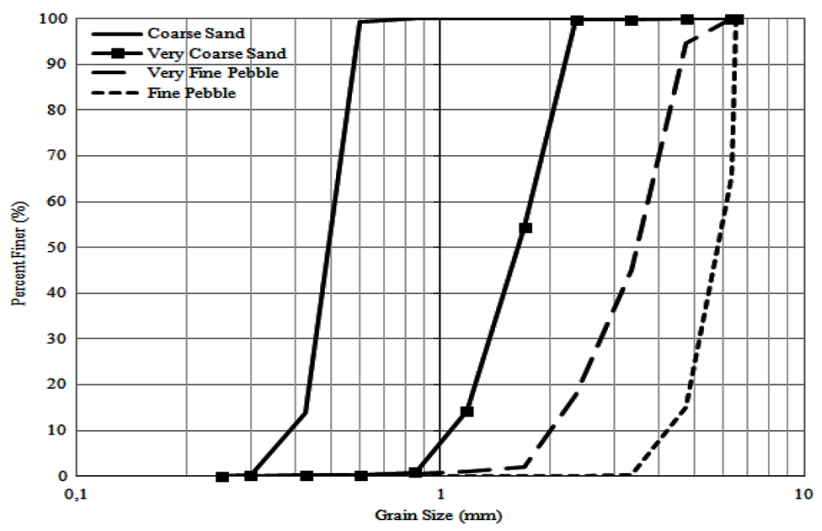

Figure 2. Particle size distributions of the bed materials

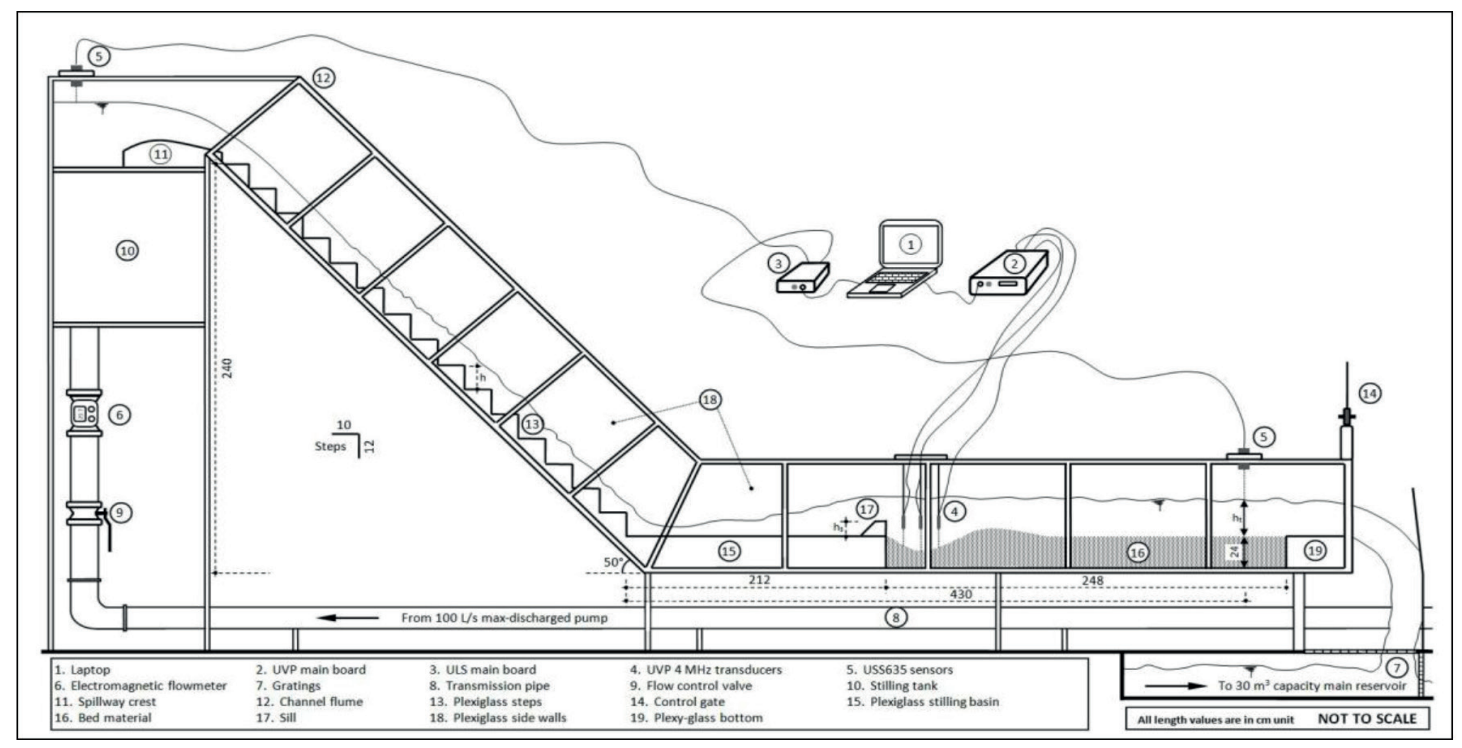

Figure 1. Schematic illustration of the experimental setup 
Table 1. Characteristic parameters of the experimental variables: $q$ is the unit flow rate, $h_{t}$ is the tail-water depth, $h_{s}$ is the sill height, $V$ is the mean water velocity, $u_{*}$ is the shear velocity and $d_{50}$ is the median grain size of the bed material

\begin{tabular}{|c|c|c|c|c|c|c|}
\hline $\begin{array}{l}\text { Exp. } \\
\text { No. }\end{array}$ & $\begin{array}{c}q \\
(273.9-840.2) \\
\left(\mathrm{cm}^{3} \cdot \mathrm{s}^{-1} \cdot \mathrm{cm}^{-1}\right)\end{array}$ & $\begin{array}{c}h_{t} \\
(14.5-24.5) \\
(\mathrm{cm})\end{array}$ & $\begin{array}{c}h_{s} \\
(5.0-7.5) \\
(\mathrm{cm})\end{array}$ & $\begin{array}{c}d_{50} \\
(0.55-5.45) \\
(\mathrm{mm}) \\
\end{array}$ & $\begin{array}{c}V \\
\left(\mathrm{~cm} \cdot \mathrm{s}^{-1}\right) \\
\end{array}$ & $\begin{array}{c}u_{*} \\
\left(\mathrm{~cm} \cdot \mathrm{s}^{-1}\right) \\
\end{array}$ \\
\hline$E-1$ & 273.9 & 14.5 & 5.0 & 0.55 & 18.89 & 1.07 \\
\hline$E-2$ & 478.5 & 17.0 & 5.0 & 0.55 & 28.15 & 1.56 \\
\hline$E-3$ & 690.3 & 19.0 & 5.0 & 0.55 & 36.33 & 1.98 \\
\hline$E-4$ & 738.3 & 20.5 & 5.0 & 0.55 & 36.01 & 1.95 \\
\hline$E-5$ & 822.7 & 21.2 & 5.0 & 0.55 & 38.81 & 2.09 \\
\hline$E-6$ & 840.2 & 21.5 & 5.0 & 0.55 & 39.08 & 2.10 \\
\hline$E-7$ & 273.9 & 16.0 & 7.5 & 0.55 & 17.12 & 0.96 \\
\hline$E-8$ & 478.5 & 18.5 & 7.5 & 0.55 & 25.86 & 1.42 \\
\hline$E-9$ & 690.3 & 20.0 & 7.5 & 0.55 & 34.52 & 1.87 \\
\hline$E-10$ & 738.3 & 21.0 & 7.5 & 0.55 & 35.16 & 1.89 \\
\hline $\mathrm{E}-11$ & 822.7 & 23.0 & 7.5 & 0.55 & 35.77 & 1.90 \\
\hline$E-12$ & 840.2 & 24.5 & 7.5 & 0.55 & 34.29 & 1.81 \\
\hline $\mathrm{E}-13$ & 273.9 & 14.5 & 5.0 & 1.85 & 18.89 & 1.29 \\
\hline E-14 & 478.5 & 17.0 & 5.0 & 1.85 & 28.14 & 1.87 \\
\hline E-15 & 690.3 & 19.0 & 5.0 & 1.85 & 36.33 & 2.38 \\
\hline$E-16$ & 738.3 & 20.5 & 5.0 & 1.85 & 36.01 & 2.33 \\
\hline E-17 & 822.7 & 21.2 & 5.0 & 1.85 & 38.81 & 2.49 \\
\hline E-18 & 840.2 & 21.5 & 5.0 & 1.85 & 39.08 & 2.51 \\
\hline E-19 & 273.9 & 16.0 & 7.5 & 1.85 & 17.12 & 1.15 \\
\hline$E-20$ & 478.5 & 18.5 & 7.5 & 1.85 & 25.86 & 1.70 \\
\hline $\mathrm{E}-21$ & 690.3 & 20.0 & 7.5 & 1.85 & 34.52 & 2.24 \\
\hline$E-22$ & 738.3 & 21.0 & 7.5 & 1.85 & 35.16 & 2.26 \\
\hline$E-23$ & 822.7 & 23.0 & 7.5 & 1.85 & 35.77 & 2.27 \\
\hline$E-24$ & 840.2 & 24.5 & 7.5 & 1.85 & 34.29 & 2.15 \\
\hline$E-25$ & 273.9 & 14.5 & 5.0 & 3.45 & 18.89 & 1.45 \\
\hline$E-26$ & 478.5 & 17.0 & 5.0 & 3.45 & 28.15 & 2.09 \\
\hline $\mathrm{E}-27$ & 690.3 & 19.0 & 5.0 & 3.45 & 36.33 & 2.65 \\
\hline$E-28$ & 738.3 & 20.5 & 5.0 & 3.45 & 36.01 & 2.59 \\
\hline$E-29$ & 822.7 & 21.2 & 5.0 & 3.45 & 38.81 & 2.77 \\
\hline$E-30$ & 840.2 & 21.5 & 5.0 & 3.45 & 39.08 & 2.78 \\
\hline E-31 & 273.9 & 16.0 & 7.5 & 3.45 & 17.12 & 1.29 \\
\hline$E-32$ & 478.5 & 18.5 & 7.5 & 3.45 & 25.86 & 1.89 \\
\hline$E-33$ & 690.3 & 20.0 & 7.5 & 3.45 & 34.52 & 2.49 \\
\hline E-34 & 738.3 & 21.0 & 7.5 & 3.45 & 35.16 & 2.51 \\
\hline E-35 & 822.7 & 23.0 & 7.5 & 3.45 & 35.77 & 2.52 \\
\hline$E-36$ & 840.2 & 24.5 & 7.5 & 3.45 & 34.29 & 2.39 \\
\hline E-37 & 273.9 & 14.5 & 5.0 & 5.45 & 18.89 & 1.60 \\
\hline$E-38$ & 478.5 & 17.0 & 5.0 & 5.45 & 28.14 & 2.31 \\
\hline E-39 & 690.3 & 19.0 & 5.0 & 5.45 & 36.33 & 2.92 \\
\hline$E-40$ & 738.3 & 20.5 & 5.0 & 5.45 & 36.01 & 2.85 \\
\hline$E-41$ & 822.7 & 21.2 & 5.0 & 5.45 & 38.81 & 3.05 \\
\hline$E-42$ & 840.2 & 21.5 & 5.0 & 5.45 & 39.08 & 3.06 \\
\hline$E-43$ & 273.9 & 16.0 & 7.5 & 5.45 & 17.12 & 1.42 \\
\hline E-44 & 478.5 & 18.5 & 7.5 & 5.45 & 25.86 & 2.09 \\
\hline E-45 & 690.3 & 20.0 & 7.5 & 5.45 & 34.52 & 2.74 \\
\hline$E-46$ & 738.3 & 21.0 & 7.5 & 5.45 & 35.16 & 2.77 \\
\hline $\mathrm{E}-47$ & 822.7 & 23.0 & 7.5 & 5.45 & 35.77 & 2.76 \\
\hline $\mathrm{E}-48$ & 840.2 & 24.5 & 7.5 & 5.45 & 34.29 & 2.62 \\
\hline
\end{tabular}

During the experiments three different measurements were performed via electromagnetic and ultrasonic techniques (Fig. 1). Flow rates were measured precisely by using the electromagnetic flow meter. Water levels were measured at 2 points along the experimental set-up by means of ULS (Ultrasonic Level Sensors (labelled 4 in Fig.1) - USS635 sensors (labelled 5 in Fig.1)). The locations of the USS635 sensors are shown in Fig. 1. The temporal scour depths were measured by using the ultrasonic velocity profiler (UVP). Three UVP transducers were located on the sediment box to detect the location of the maximum scour depth. Although, the UVP device is designed mainly to obtain the velocity profile, in this study it was used to determine the time-varying bed material motion in an indirect way by placing UVP transducers vertically. A detailed explanation can be found in the study of Guney et al. (2013).

The characteristic values of the experimental parameters are given in Table 1 . The efficient and substantial nondimensional parameters are shown in Table 2.

\section{RESULTS AND DISCUSSION}

Experiments were carried out to determine temporal scour variation at the downstream of the stepped channel under different experimental conditions. In order to investigate the effect of the bed material, sill height and flow rate, 4 different bed materials, 2 different sill heights and 6 different flow rates were used. According to the experimental results, scour depth is a function of sill height, tailwater depth and bed material characteristics. Bed material was varied between $0.55 \mathrm{~mm}$ and $5.45 \mathrm{~mm}$. Temporal variation of scour depth measured at the centreline of the flume for constant sill height and grain size of the bed material under different flow rates and tailwater depths is given in Fig. 3. According to the experimental results it is revealed that the scour depth increased with the mean flow velocity in all experiments. Maximum scour depth occurred in the case of minimum grain size of the bed material, maximum rate of the flow velocity and lower sill height. The scour depth decreased with an increase in both sill height and median grain size of bed material, as expected. The scour depth builds up over time and when the scour depth reaches its maximum value it fluctuates around the maximum value. The final scour depth values observed at the end of each experiment are given in Table 3 .

Least squares method was used to obtain the bestfitting curve by minimizing the sum of the squares of the residuals between observed and calculated values. Equation 5 and Equation 6 are proposed by using the experimental data obtained from the present study. The powers of non-dimensional parameters in the proposed equations were obtained by means of the least squares method. The differences between these two equations are the third terms. Shields parameter $(\theta)$ was used in Eq. 5 while densimetric Froude particle number $\left(F_{\mathrm{d}}\right)$ was used in Eq. 6. To calculate the value of the Densimetric Froude particle number only mean water velocity $(V)$ is used, but to calculate the value of the Shields parameter, shear velocity $\left(u_{*}\right)$ should first be calculated. The calculated scour depths obtained by using these equations were compared with those measured during the experiments. Figure 4 represents measured and computed temporal variation of scour depth. Based on Fig. 4 one can say that the measured and computed scour depths are in good agreement.

$$
\frac{d_{s}}{h}=0.47\left(\frac{h_{t}}{h}\right)^{0.65} \theta^{0.1}\left(1-e^{-0.1 T}\right)
$$


Table 2. Summary of the non-dimensional parameters. $\operatorname{Re}_{d}$ is the grain Reynolds number and it can be defined as $u_{*} \cdot d_{50} / v \cdot \theta$ and $F_{d}$ are the Shields parameter and the densimetric Froude particle number, respectively.

\begin{tabular}{|c|c|c|c|c|}
\hline $\begin{array}{l}\text { Experiment } \\
\text { Number }\end{array}$ & $\mathrm{Re}_{d}$ & $\theta$ & $F_{\mathrm{d}}$ & $\frac{h_{t}}{h}$ \\
\hline $\mathrm{E}-1$ & 5.9 & 0.0129 & 2.0 & 1.21 \\
\hline$E-2$ & 8.6 & 0.0273 & 3.0 & 1.42 \\
\hline$E-3$ & 10.9 & 0.0442 & 3.9 & 1.58 \\
\hline$E-4$ & 10.7 & 0.0425 & 3.8 & 1.71 \\
\hline E-5 & 11.5 & 0.0489 & 4.1 & 1.77 \\
\hline E-6 & 11.5 & 0.0494 & 4.1 & 1.79 \\
\hline$E-7$ & 5.3 & 0.0103 & 1.8 & 1.33 \\
\hline$E-8$ & 7.8 & 0.0225 & 2.7 & 1.54 \\
\hline E-9 & 10.3 & 0.0393 & 3.7 & 1.67 \\
\hline E-10 & 10.4 & 0.0402 & 3.7 & 1.83 \\
\hline E-11 & 10.5 & 0.0407 & 3.8 & 1.92 \\
\hline E-12 & 9.9 & 0.0367 & 3.6 & 2.04 \\
\hline E-13 & 23.9 & 0.0056 & 1.1 & 1.21 \\
\hline E-14 & 34.7 & 0.0117 & 1.6 & 1.42 \\
\hline E-15 & 44.0 & 0.0189 & 2.1 & 1.58 \\
\hline E-16 & 43.0 & 0.0181 & 2.1 & 1.71 \\
\hline E-17 & 46.1 & 0.0208 & 2.2 & 1.77 \\
\hline E-18 & 46.3 & 0.0210 & 2.3 & 1.79 \\
\hline E-19 & 21.3 & 0.0044 & 1.0 & 1.33 \\
\hline$E-20$ & 31.4 & 0.0096 & 1.5 & 1.54 \\
\hline $\mathrm{E}-21$ & 41.4 & 0.0167 & 2.0 & 1.67 \\
\hline $\mathrm{E}-22$ & 41.8 & 0.0171 & 2.0 & 1.83 \\
\hline E-23 & 42.0 & 0.0172 & 2.1 & 1.92 \\
\hline$E-24$ & 39.8 & 0.0155 & 2.0 & 2.04 \\
\hline E-25 & 49.9 & 0.0037 & 0.8 & 1.21 \\
\hline$E-26$ & 72.2 & 0.0078 & 1.2 & 1.42 \\
\hline E-27 & 91.3 & 0.0125 & 1.5 & 1.58 \\
\hline$E-28$ & 89.2 & 0.0120 & 1.5 & 1.71 \\
\hline$E-29$ & 95.6 & 0.0137 & 1.6 & 1.77 \\
\hline$E-30$ & 96.0 & 0.0139 & 1.7 & 1.79 \\
\hline$E-31$ & 44.4 & 0.0030 & 0.7 & 1.33 \\
\hline$E-32$ & 65.3 & 0.0064 & 1.1 & 1.54 \\
\hline E-33 & 85.9 & 0.0111 & 1.5 & 1.67 \\
\hline E-34 & 86.7 & 0.0113 & 1.5 & 1.83 \\
\hline E-35 & 86.8 & 0.0113 & 1.5 & 1.92 \\
\hline$E-36$ & 82.3 & 0.0102 & 1.5 & 2.04 \\
\hline E-37 & 92.2 & 0.0028 & 0.6 & 1.21 \\
\hline$E-38$ & 132.9 & 0.0057 & 0.9 & 1.42 \\
\hline E-39 & 167.7 & 0.0091 & 1.2 & 1.58 \\
\hline$E-40$ & 163.7 & 0.0087 & 1.2 & 1.71 \\
\hline$E-41$ & 175.3 & 0.0100 & 1.3 & 1.77 \\
\hline$E-42$ & 176.0 & 0.0101 & 1.3 & 1.79 \\
\hline E-43 & 81.8 & 0.0022 & 0.6 & 1.33 \\
\hline E-44 & 120.0 & 0.0047 & 0.8 & 1.54 \\
\hline E-45 & 157.7 & 0.0081 & 1.1 & 1.67 \\
\hline E-46 & 159.1 & 0.0082 & 1.2 & 1.83 \\
\hline$E-47$ & 159.0 & 0.0082 & 1.2 & 1.92 \\
\hline E-48 & 150.6 & 0.0074 & 1.1 & 2.04 \\
\hline
\end{tabular}

$$
\frac{d_{s}}{h}=0.30\left(\frac{h_{t}}{h}\right)^{0.55} F_{d}^{0.15}\left(1-e^{-0.1 T}\right)
$$

Table 3. Final scour depth values

\begin{tabular}{|c|c|c|c|}
\hline $\begin{array}{l}\text { Experiment } \\
\text { Number }\end{array}$ & $\begin{array}{c}d_{s}^{f} \\
(\mathrm{~mm})\end{array}$ & $\begin{array}{c}\text { Experiment } \\
\text { Number }\end{array}$ & $\begin{array}{c}d_{s}^{f} \\
(\mathrm{~mm})\end{array}$ \\
\hline E-1 & 46.3 & E-25 & 41.2 \\
\hline E-2 & 51.9 & E-26 & 46.5 \\
\hline E-3 & 57.0 & E-27 & 48.8 \\
\hline E-4 & 61.7 & $\mathrm{E}-28$ & 52.6 \\
\hline E-5 & 64.0 & E-29 & 53.2 \\
\hline E-6 & 64.9 & E-30 & 54.3 \\
\hline E-7 & 44.6 & E-31 & 40.6 \\
\hline E-8 & 48.3 & E-32 & 45.6 \\
\hline E-9 & 55.0 & E-33 & 47.7 \\
\hline E-10 & 57.0 & E-34 & 49.7 \\
\hline E-11 & 58.5 & E-35 & 51.0 \\
\hline E-12 & 59.4 & E-36 & 52.3 \\
\hline E-13 & 42.3 & E-37 & 40.5 \\
\hline E-14 & 48.0 & E-38 & 44.0 \\
\hline E-15 & 50.5 & E-39 & 48.0 \\
\hline E-16 & 55.7 & $\mathrm{E}-40$ & 51 \\
\hline E-17 & 57.2 & E-41 & 52.3 \\
\hline E-18 & 58.2 & E-42 & 53.0 \\
\hline E-19 & 41.0 & E-43 & 39.7 \\
\hline E-20 & 46.5 & E-44 & 43.0 \\
\hline E-21 & 48.5 & E-45 & 46.8 \\
\hline E-22 & 51.9 & E-46 & 48.8 \\
\hline E-23 & 52.5 & E-47 & 50.1 \\
\hline E-24 & 53.5 & E-48 & 51.5 \\
\hline
\end{tabular}

where $T$ is the dimensionless time parameter which can be expressed as follows:

$$
T=\frac{\sqrt{g^{\prime d_{50}}}}{h} t
$$

where $t$ is time.

Equations 5 and 6 were evaluated in terms of scatter index (SI) defined as follows:

$$
S I(\%)=\frac{\sqrt{\frac{\sum_{i=1}^{n}\left(d_{s, \text { measured }_{i}}-d_{s, \text { computed }_{i}}\right)^{2}}{n}}}{d_{s, \text { measured }}} \cdot 100
$$

The SI values were $8.73 \%$ and $8.25 \%$ for Eq. 5 and Eq. 6 , respectively. According to the SI (\%) values it is revealed that both equations can be used to predict temporal scour depth values.

The dimensionless scour depth values $\left(d_{s}^{f} / h\right)$ obtained at the end of the experiments were plotted versus Shields parameter $(\theta)$ and densimetric Froude particle number $\left(F_{d}\right)$ and given in Figs 5 and 6. Dimensionless scour depth increases with both Shields parameter $(\theta)$ and densimetric Froude particle number $\left(F_{d}\right)$.

Maximum scour depths, measured after each experiment, were also compared with those calculated using Eqs 5 and 6 . The results are given in Fig. 7 .

The $R^{2}$ (coefficient of determination) values were computed as 0.866 and 0.865 for Eq. 5 and Eq. 6, respectively. These results also support the results obtained by using SI (\%) values.

To check the validity of the proposed equations the Fisher $(f)$ test was also applied. The parameter $f$ is defined as follows: 

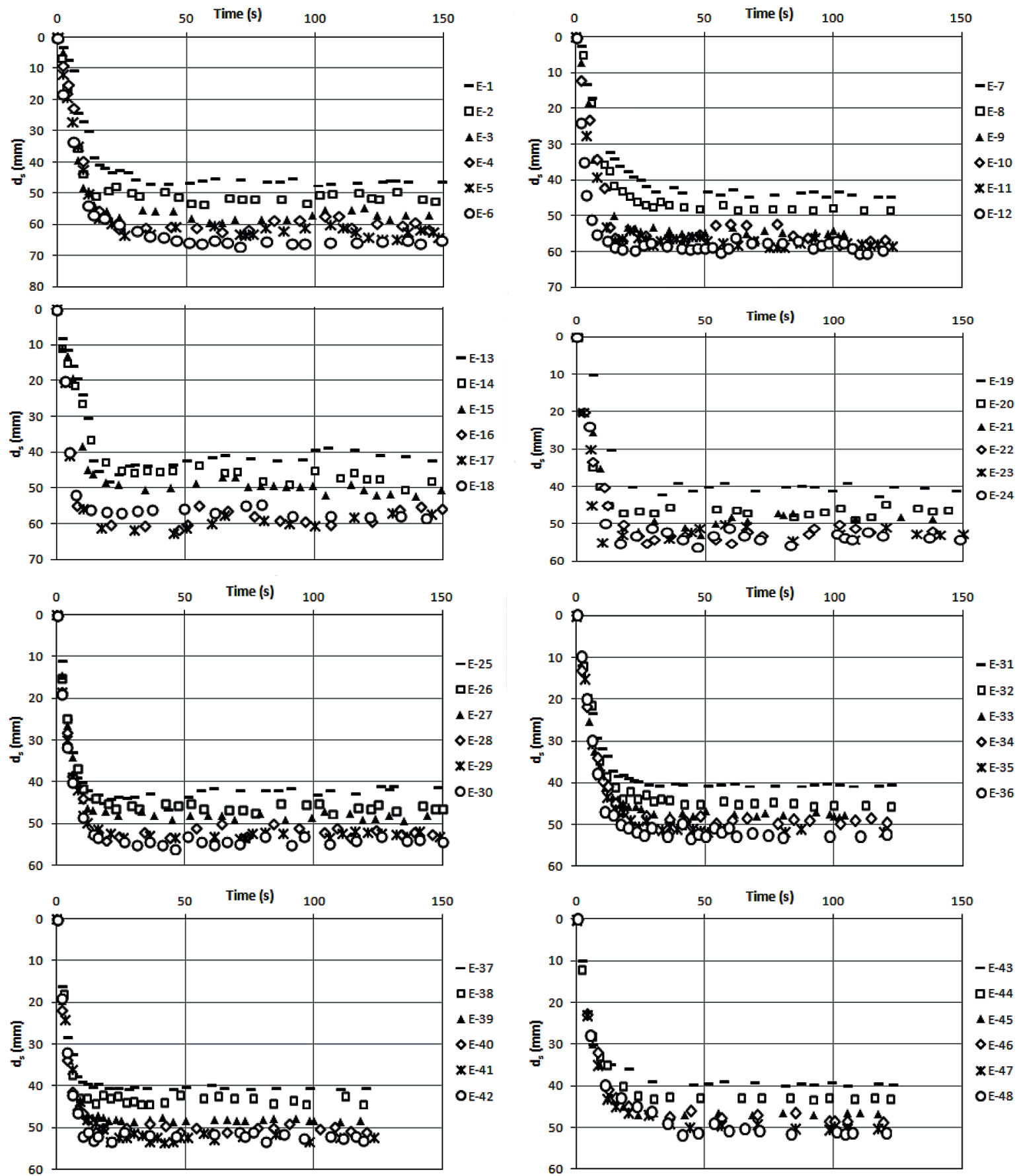

Figure 3. Temporal variation of scour depth measured during the experiments

$$
f=\frac{S S R / v_{1}}{S S E / v_{2}}
$$

where SSR is the sum of squared residuals, SSE is the sum of squares for error, $v_{1}$ is the number of the independent variables $(k)$, and $v_{2}=n-k-1,(n$ is the number of data points). SSR and SSE can be calculated from the following equations:

$$
\begin{gathered}
S S R=\sum_{i=1}^{n}\left(d_{s i}^{\text {computed }}-\overline{d_{s i}^{\text {measured }}}\right)^{2} \\
S S E=\sum_{i=1}^{n}\left(d_{s i}^{\text {measured }}-d_{s i}^{\text {computed }}\right)^{2}
\end{gathered}
$$

where $\overline{d_{s i}^{\text {measured }}}$ and $\overline{d_{s i}^{\text {computed }}}$ are the arithmetic mean of the measured and computed scour depth values, respectively.

For the selected 0.01 significance level, the critical value of $f$ is 4.22. If the computed $f$ value is greater than the critical value that means that the fit of the proposed equation is statistically significant. The $f$ values were computed as 66.3 and 65.1 for Eqs 4 and 5, respectively. Therefore, one can say that the proposed equations were acceptable.

As a consistent estimator, sum of squared errors (SSE) was computed for Eq. 5 and Eq. 6. SSE is the error between the measured and computed values: 

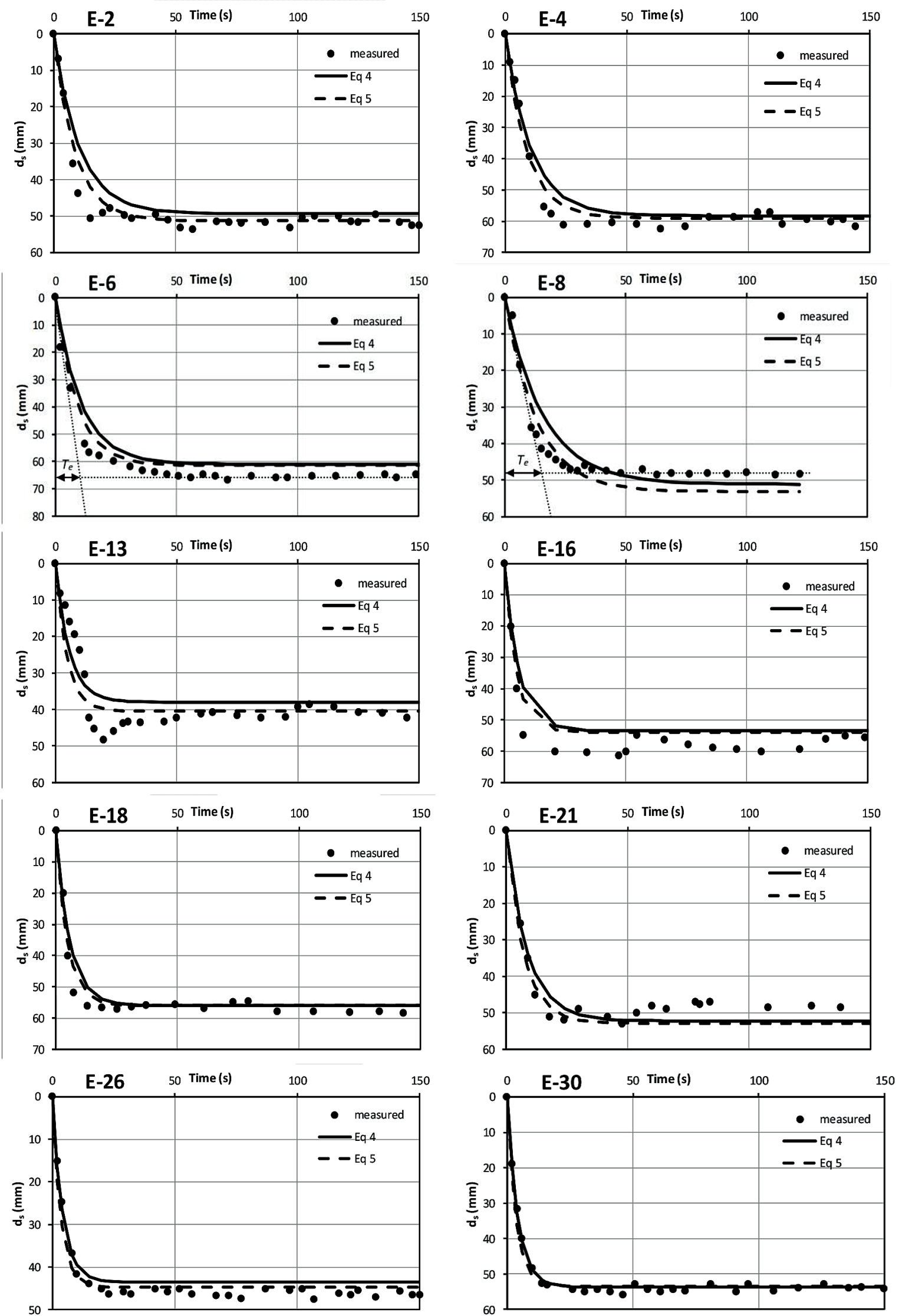

Figure 4. Measured and calculated scour depth values 

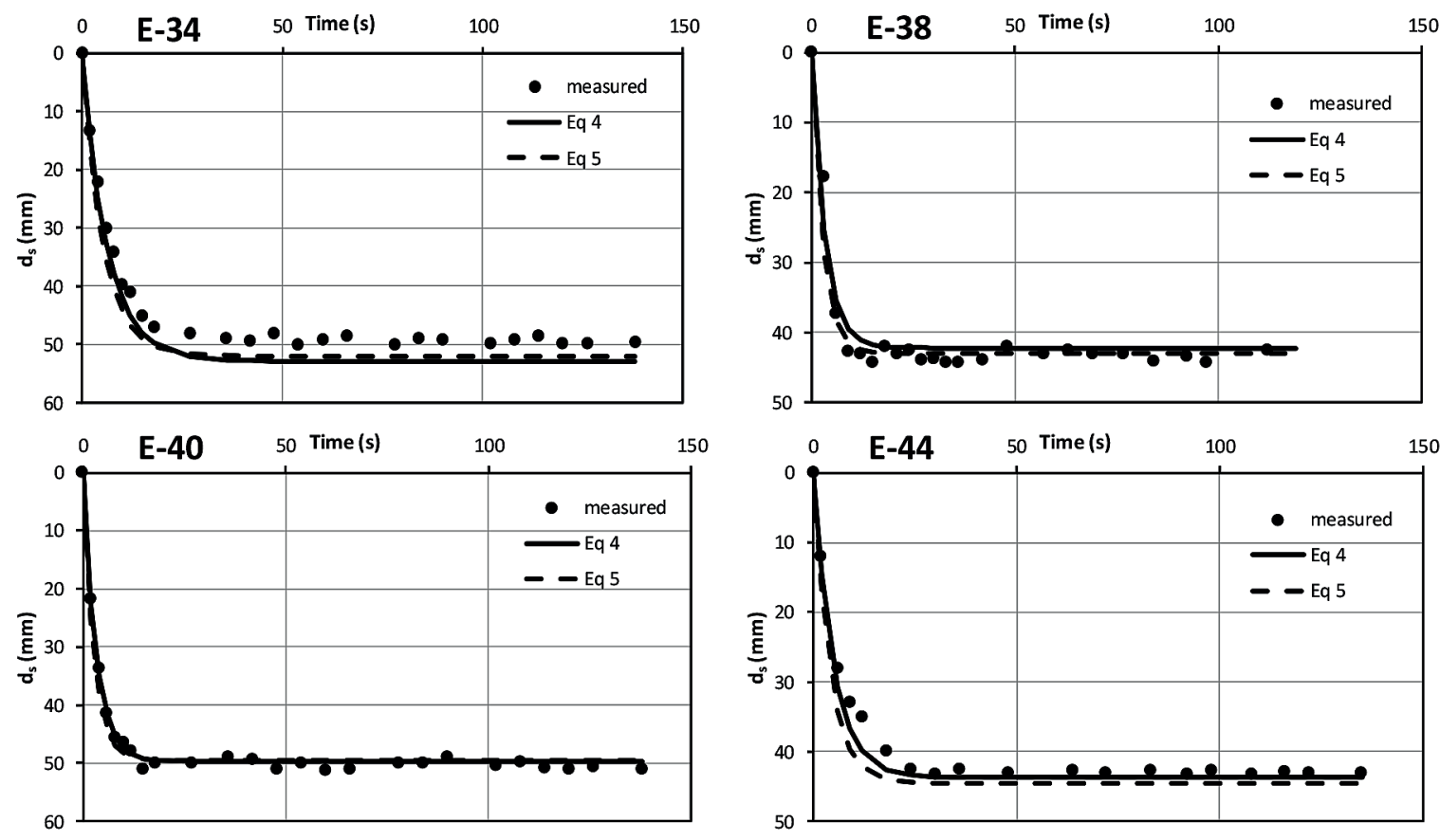

Figure 4. (cont.)

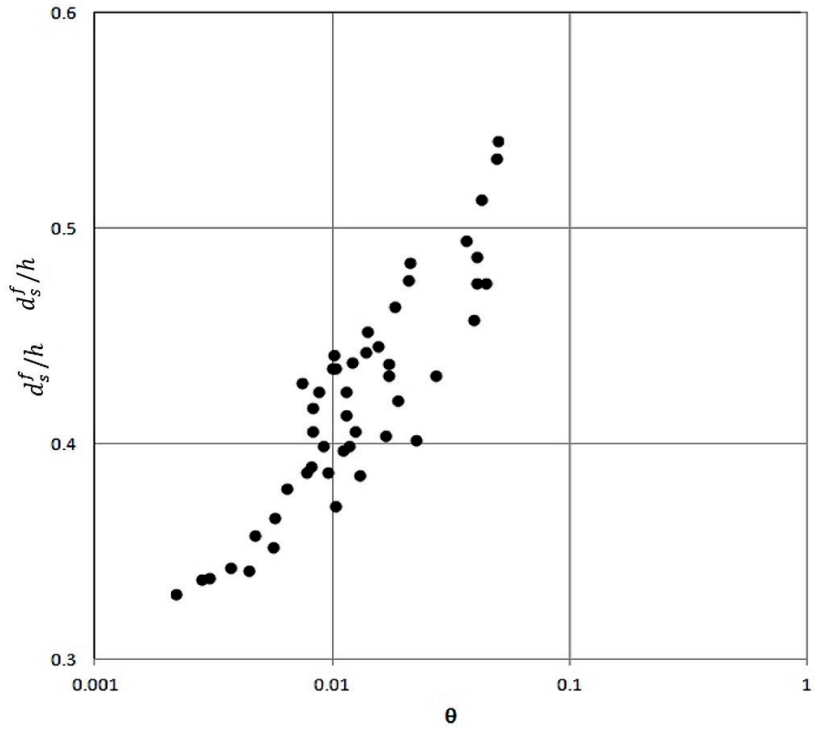

Figure 5. Dimensionless scour depth values $\left(d_{s}^{f} / h\right)$ versus Shields parameter $(\theta)$

$$
\operatorname{SSE}(\%)=\frac{\sum\left(d_{s, \text { measured }}-d_{s, \text { computed }}\right)^{2}}{\sum\left(d_{s, \text { measured }}\right)^{2}} \cdot 100
$$

The SSE values were calculated as $0.24 \%$ and $0.23 \%$ for Eqs 5 and 6 , respectively. According to the statistical results it was revealed that the proposed equations are acceptable.

In the present study, the time scale parameter $\left(T_{e}\right)$ was also investigated. The time scale can be described as the time period in which the scour depth reaches the equilibrium stage. The values of the time scale $\left(T_{e}\right)$ were determined from the timedependent scour depth graphics for each experiment. The nondimensional time scale $\left(T_{e}^{*}\right)$ parameter can be defined as:

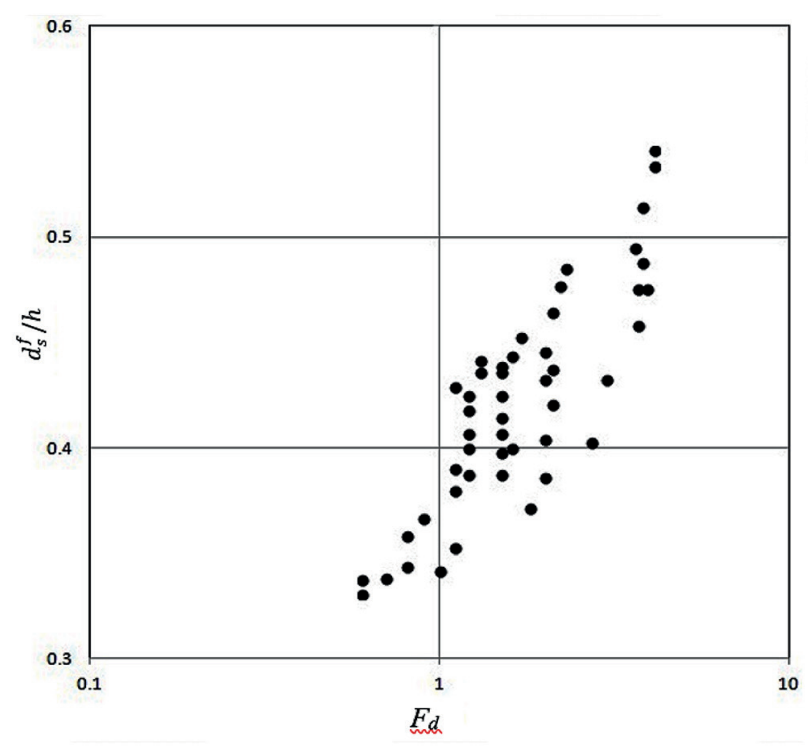

Figure 6. Dimensionless scour depth values $\left(d_{s}^{f} / h\right)$ versus densimetric Froude particle number $\left(F_{d}\right)$

$$
T_{e}^{*}=\frac{\sqrt{g^{\prime} d_{50}}}{h} T_{e}
$$

Based on the experimental findings two relationships between $T_{e}^{*}$ versus $\theta$ and $T_{e}^{*}$ versus $F_{d}$ are proposed. Equations 14 and 15 are the empirical equations to estimate the time scale parameter for the scour process at the downstream part of the stepped channels. The powers of these relations were also obtained by means of the least squares method. So these powers give the best fit. 


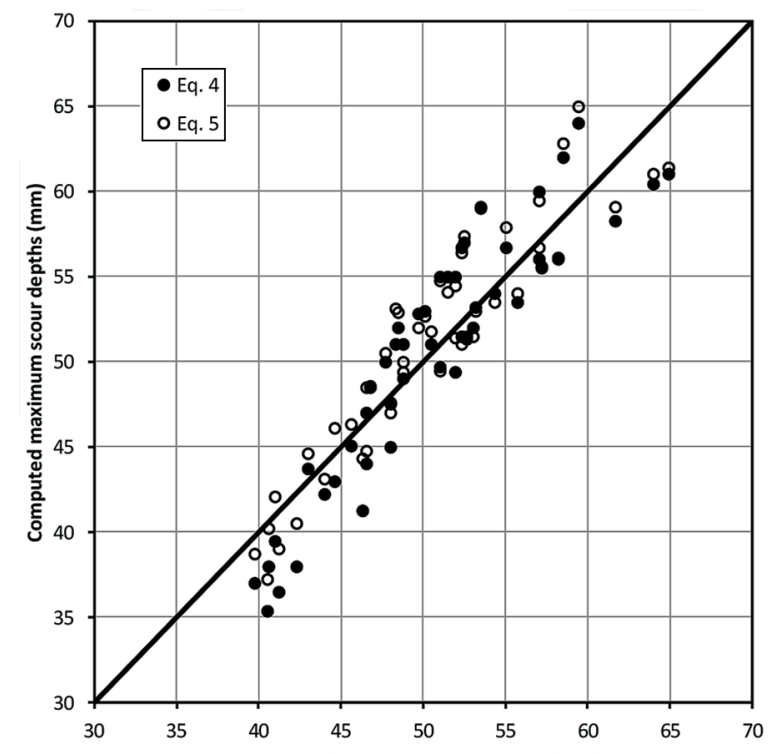

Figure 7. Measured and computed scour depth values

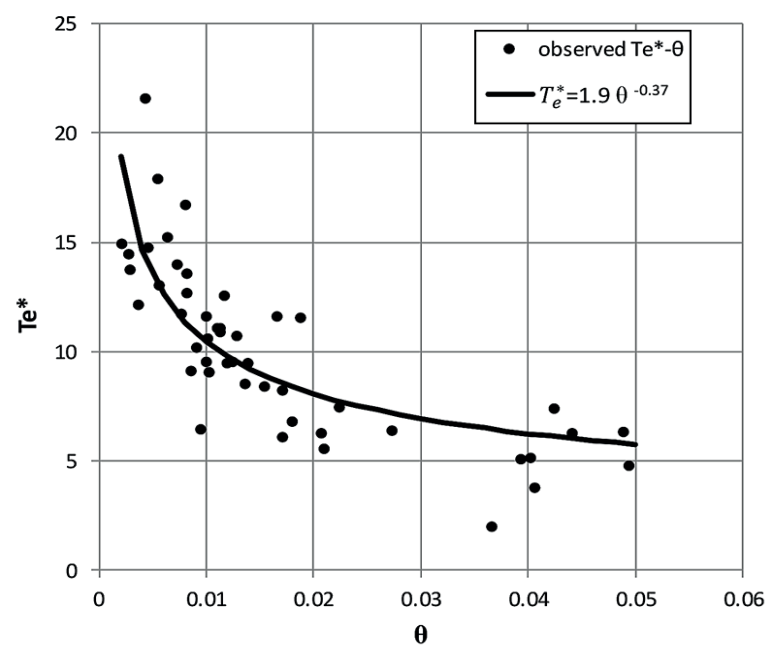

Figure 8. Non-dimensional time scale values versus Shields parameter

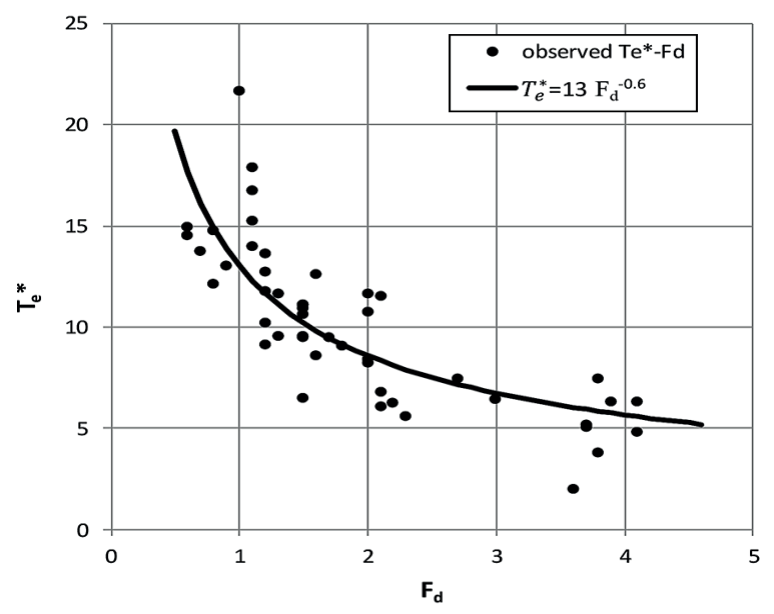

Figure 9. Non-dimensional time scale values versus densimetric Froude particle number

$$
\begin{aligned}
& T_{\mathrm{e}}^{*}=1.9 \theta^{-0.37} \\
& T_{\mathrm{e}}^{*}=13 F_{d}^{-0.6}
\end{aligned}
$$

The observed non-dimensional time scale $\left(T_{e}^{*}\right)$ values were compared with those calculated by using Eq. 14 and Eq. 15, as shown in Fig. 8 and Fig. 9, respectively.

\section{CONCLUSIONS}

In this study, temporal local scour variations at the downstream part of a stepped channel were investigated experimentally. Four different bed materials, two different sill heights and six different flow rates were used. Two empirical equations predicting the temporal variation of scour depth were proposed using the experimental findings. The validity of the equations was also investigated. The following conclusions can be drawn from the results of this study:

- The scour depth increased with the mean flow velocity and the maximum scour depth occurred in the case of minimum grain size of the bed material, maximum rate of the flow and lower sill height

- The scour depth decreased with an increase in both sill height and median grain size of bed material

- The dimensionless scour depth $\left(d_{s} / h\right)$ increases with both Shields parameter $(\theta)$ and densimetric Froude particle number $\left(F_{d}\right)$

- The temporal variation of scour depth was calculated by means of Eq. 5 and Eq. 6, which include Shields parameter $(\theta)$ and densimetric Froude particle number $\left(F_{d}\right)$, respectively. The results of both equations are in good agreement with experimental findings.

- To indicate the best-fit equation scatter index (SI\%) values were computed for both equations by using the observed and calculated temporal variations of the scour depth. There is not a significant difference between the SI values and it is revealed that both equations can be used to predict temporal scour depth variation.

- A Fisher $(f)$ test was performed to check the statistical significance of the proposed equations. The computed $f$ values for both equations are larger than the critical value of $f$ determined for the selected 0.01 significance level. Therefore, the significance of the proposed equations was confirmed.

- $\quad$ The SSE\% values were calculated as $0.24 \%$ and $0.23 \%$ for Eq. 5 and Eq. 6, respectively. According to the statistical results it is revealed that the proposed equations are acceptable.

- According to the time-dependent experimental results; Eq. 14 and Eq. 15 were proposed to estimate the nondimensional time scale values which is the time period during the equilibrium scour develops.

\section{REFERENCES}

AMINPOUR Y, FARHOUDI J, SHAYAN HK and ROSHAN R (2016) Characteristics and time scale of local scour downstream stepped spillways. Sci. Iranica 25 (2) 532-542. https://doi.org/10.24200/ sci. 2017.4187

BREUSERS HNC and RAUDKIVI AJ (1991) Scouring Hydraulic Structures Design Manual. A. A. Balkema, Rotterdam.

CHANSON H (1994) Hydraulics of skimming flows over stepped channels and spillways. J. Hydraul. Res. 32 345-460. https://doi. org/10.1080/00221689409498745

DEY S and RAIKAR RV (2005) Scour in long contractions. J. 
Hydraul. Eng. 131 (12) 1036-1049. https://doi.org/10.1061/ (asce)0733-9429(2005)131:12(1036)

ELNIKHELY EA (2017) Investigation and analysis of scour downstream of a spillway. Ain Shams Eng. J. https://doi. org/10.1016/j.asej.2017.03.008

FARHOUDI J and SHAYAN HK (2014) Investigation on local scour downstream of adverse stilling basins. Ain Shams Eng. J. 5 361-375. https://doi.org/10.1016/j.asej.2014.01.002

GUNEY MS, BOMBAR G, OZGENC AKSOY A and DOGAN M (2013) Use of Uvp to investigate the evolution of bed configuration. KSCE J. Civ. Eng. 17 (5) 1-10. https://doi.org/10.1007/s12205-013-0131-5

HASSAN MK and NARAYANAN R (1985) Local scour downstream of an apron. J. Hydraul. Eng. 111 (11) 1371-1385.

OLIVETO G and COMUNIELLO V (2009) Local scour downstream of positive-step stilling basins. J. Hydraul. Eng. 135 (10) 846-851. https://doi.org/10.1080/00221686.2010.538593
Oliveto G, COMUNiELlO V and BUlbulE T (2011) Timedependent local scour downstream of positive-step stilling basins. J. Hydraul. Res. 49 (1) 105-112. https://doi.org/10.1080/00221686.2 010.538593

OLIVETO G and HAGER WH (2002) Temporal evolution of clearwater pier and abutment scour. J. Hydraul. Eng. 128 (9) 811-820. https://doi.org/10.1061/(asce)0733-9429(2002)128:9(811)

TUNA MC and EMIROGLU ME (2011) Scour profiles at downstream of cascades. Sci. Iranica 18 (3) 338-347. https://doi.org/10.1016/j. scient.2011.05.040

TUNA MC (2012) Effect of offtake channel base angle of stepped spillway on scour hole. IJST, Trans. Civ. Eng. 36 (C2) 239-251.

TUNA MC and EMIROGLU ME (2013) Effect of step geometry on local scour downstream of stepped chutes. Arab. J. Sci. Eng. 38 579-588. https://doi.org/10.1007/s13369-012-0335-x 